\title{
FROM SMART CITIES TO SMART REGIONS: REGIONAL ECONOMIC SPECIALIZATION AS A TOOL FOR DEVELOPMENT AND INCLUSION
}

\author{
Karina Radchenko ${ }^{1}$
}

\begin{abstract}
Keeping in mind that the fundamental task of local and regional governments is improving lives of their citizens, this paper considers the phenomenon of smart specialization as a tool that can be used to reach economic development and inclusion. Particular attention is paid to the impacts of smart cities on regional life through establishing smart city networks and mutual cooperation of various stakeholders. The issues associated with smart specialization are determined. At the same time, it is attempted to suggest the possible steps that could be taken by local and regional authorities to foster smartification. The multidimensional methodology approach is used for this study to increase its comprehensiveness and wider applicability of the concluding recommendations. The research is directly linked to the UN Sustainable Development Goals that are actively promoted by the Congress of Local and Regional Authorities of the Council of Europe, so it is related to high practical and theoretical value.
\end{abstract}

\section{Introduction}

The digital era of massive use of information and communication technologies has set the new environment for local and regional authorities to deal with. The smart cities are viewed as the fastgrowing trend of the last decade. The researches have already proved the distributional effects of smartification on people, planet and places. [14] Moreover, targeted application of smart city concept may significantly increase the efficiency of public policies. [29; 21] At the same time, specific impact scenarios of smartification may be noticed in different communities proving the high value of the targeted case-by-case approach. [25]

It should be noted that cooperating inter alia, smart cities are likely to lead to larger territorial cohesion positively affecting regional development. [30] Such cooperation may take place in various forms including regional clustering, smart city networks, and smart specialization. [31] [21] [13] According to the report presented by the European Committee of the Regions, smart specialization also provides better regional economic competitiveness, larger citizens welfare and higher sustainability. [25] [12] [7] Therefore, there are reasons to consider smart specialization as a tool that could be intentionally used by local and regional governance to advance economic development and inclusivity as well as unleash unique territorial potential. It is important to define strategies that may be used by local and regional governments to derive maximum benefits from smart specialization and integrate smartification within their systemic operational frameworks.

\footnotetext{
${ }^{1}$ Taras Shevchenko National University of Kyiv, Volodymyrska Street, 60, Kyiv, Ukraine, karinar0546@gmail.com, http://www.univ.kiev.ua/en/
} 


\section{Research Findings}

\subsection{Defining Smart Cities}

As of now, multiple definitions of smart city co-exist, so it is worth considering some widely accepted definitions referring to particular examples of European countries. The OECD views smart cities as iniatives or approaches leveraging digitalization to boost citizen's well-being and provide more efficient, sustainable and inclusive urban services and environments as a part of the collaborative, multi-stakeholder process. [14]

Based on this definition, the role of public authorities, in context of smartification, can be defined as follows:

- $\quad$ empowering extensive collaboration within/between cities as well as among private, public and individual stakeholders on local, regional and national levels;

- $\quad$ promoting citizen's engagement (intensifying civic participation and partnership using cocreation and co-production models, delivering citizen-focused services, creating smart collaborative platforms);

- $\quad$ ensuring equal public access to open data and advancing inclusivity principles;

- developing unified, integrated strategy of addressing the urbanization-caused challenges through implementing innovative digital solutions in a city governance, planning and infrastructure investment;

- documenting and researching the impacts of smart cities on community life, tracking the city performance and ensuring maximum contribution to improving a citizen's life through setting the smart indicators.

The understanding of smart city concept in particular countries has been largely determined by the peculiarities of its practical embodiment. The volatility of such reflection of smart models in a practical realm causes evolving of the core definition. For instance, the Latvian authorities view smart cities as cities that develop and implement a set of measures aimed at tackling challenges, increasing competitiveness of an area and ensuring flexible solutions. In Spain, the government stresses the holistic nature of smart cities such as enabling real-time efficient interaction between cities and citizens as well as ensuring sustainable economic, social and environmental solutions. According to the United Kingdom Department of Business, Energy and Industrial Strategy, the concept of smart cities is viewed as a constantly changing, gradually evolving process or set of flexible steps that could be used to better adjust to challenges. [14] The most successful smart cities are based on four pillars of comprehensive development-institutional, physical, social and economic modernizations. [13] 


\subsection{Economic and Social Impacts of Smart Cities}

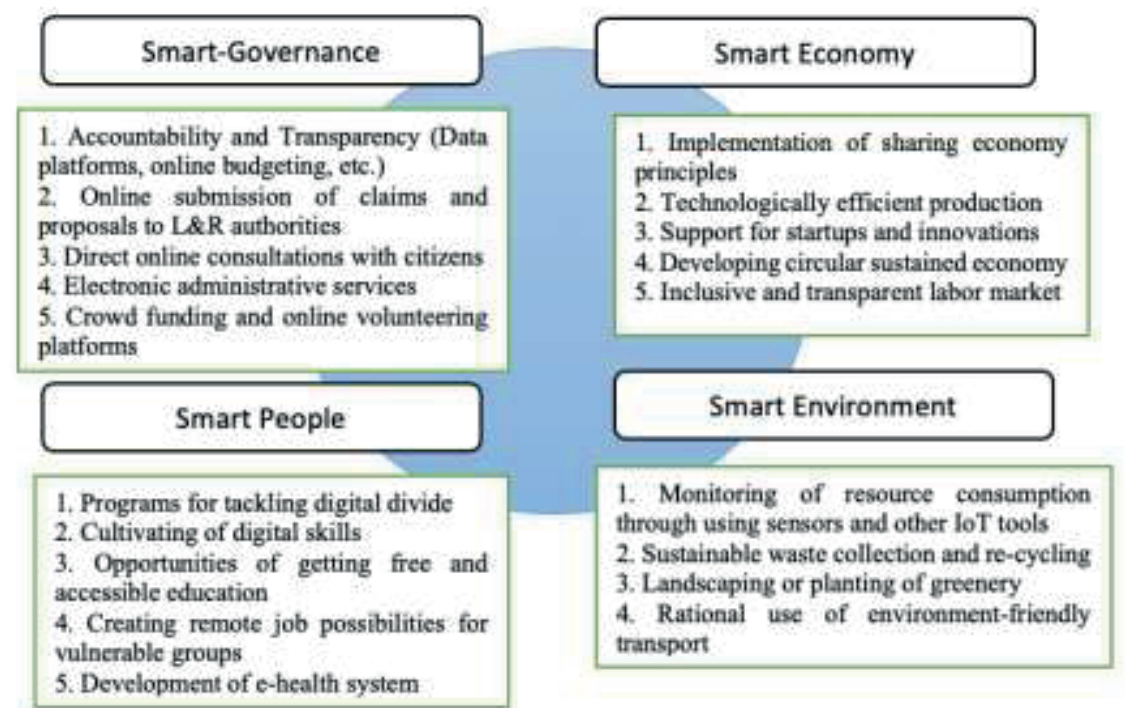

Figure 1: Smart-City Inclusive System as an interplay of essential components ${ }^{2}$

As presented in Figure 1., Smart City means comprehensive cooperation, in terms of four aspects such as smart government, smart people, smart environment, and smart economy. The smart economy and social well-being are targeted scopes of smartification. So, smart city concept invokes positive effects on particular areas providing social and economic well-being.

Cities function as engines of economic growth dominating local and regional economies. In fact, this idea has been invoking a lot of interest and discussions in international circles of respective institutions including World Bank (from Urban Policy and Economic Development: An Agenda for the 1990s (1991)) to more recent works), UN, European Commission, Commission on Growth and Development, the Global Commission for the Economy and Climate, etc. [31] The intensification of economic effects imposed by smart cities is expected in the nearest future. The ABI Research has predicted the smartification-caused impact on economic development and GDP growth by 2026. Smart cities are associated with more than $20 \$$ trillion of additional economic benefits. [24] Another white paper initiated by Inter Digital points out that the following dimensions are supposed to be most impacted by smart technologies:

- $\quad$ Open Data Policies

- $\quad$ Public Investments Multiplier Effect

- Structural Urban Economy Growth.

It should be noted that open data policies are associated with a potential incremental GDP growth of about \$1 trillion with no investments related to physical infrastructure. Smartification is likely to cause the public investment multiplication effect up to 10 times resulting in $\$ 10$ trillion of incremental GDP increase. The $2.8 \%$ structural urban economy growth increase is viewed as triggered by innovative technologies such as artificial intelligence and blockchain. [27] These findings proved the correlation between implementation of smart city technologies and economic growth. At the same time, it is important to consider whether these predicted benefits can be operationalized and captured

\footnotetext{
${ }^{2}$ Created by Author
} 
through targeted investment in smart-cities. Both economic growth and technological drivers for economic development are identified as dependent on the city smartification.

Smart-cities create more opportunities for direct citizen's participation in social, political and economic life, so the system of local and regional governance becomes more flexible and humanoriented. Such environment leads to improved work performance and higher social stability. The implementation of digital economy is likely to minimize corruption increasing transparency. In terms of right application of smart concept, no place is likely to be left for shadow economy as it will be eradicated by digital open data and e-democracy system.

In fact, economy is gradually transformed into cognitive self-powered entities integrated in one innovative network. Smart economy provides practical tools for engaging all groups of citizens into the smart system of participation, decision-making, employment, etc. [28] Tackling digital divide of unequal access to resources, technology, education and decision-making is an essential part of achieving inclusivity. For instance, a city of Lucca in Italy, has implemented several initiatives in order to be more accessible to all. It cooperates with disabled people to test new solutions for historical towns and take practical suggestions based on real needs.

It should be noted that we suggest to understand inclusivity in two contexts. The first one is active engagement of certain groups of people into economic and social life of the community. Without special policies such people could be excluded or marginalized. The second is creating advanced social-oriented interplay environment improving the well-being of each citizen through providing extended opportunities for self-development and realization. In terms of smart cities, inclusivity does not come automatically requiring sustained efforts from interplaying stakeholders such as governments, universities, business and individual citizens. Though in theory the concept Smart 3.0 is viewed as incorporating inclusivity component in contrast to Smart 1.0 rather associated with technical innovations to make inclusivity be revealed in practice commitment of the mentioned stakeholders and Inclusivity KPIs shall be implemented.

\subsection{Smart Cities and Regional Smart Specialization}

The common definition of Smart Specialization is a comprehensive policy concept aimed at enhancing regional innovation through helping regions to focus on their strengths. [11] Investments in smart specialization (RIS3) are likely to have an accelerative impact on the regional economy. Smart specialization diversifies the structure of regional economy creating new profile areas that booster economic growth and provide more jobs. The bottom-up cooperation model involving local authorities, scientific circles, business, and civil society ensures comprehensiveness and inclusivity of the proposed model. Smart specialization is a relatively new concept synthesizing the theories of the division of labor and trade specialization suggested by Adam Smith [14], as well as an agglomeration and evolutionary economy [11].

In recent time, more attention is paid to the local context of smart specialization. Smart cities and smart specialization are viewed as interdependent phenomena. Regional smart specialization accelerates local smartification, while smart cities are essential components of the specialized smart networks. [23] The local and metropolitan authorities tend to comply with the regional specialization processes as well as vice versa achieve synergy-caused positive effects. [23] [15] 


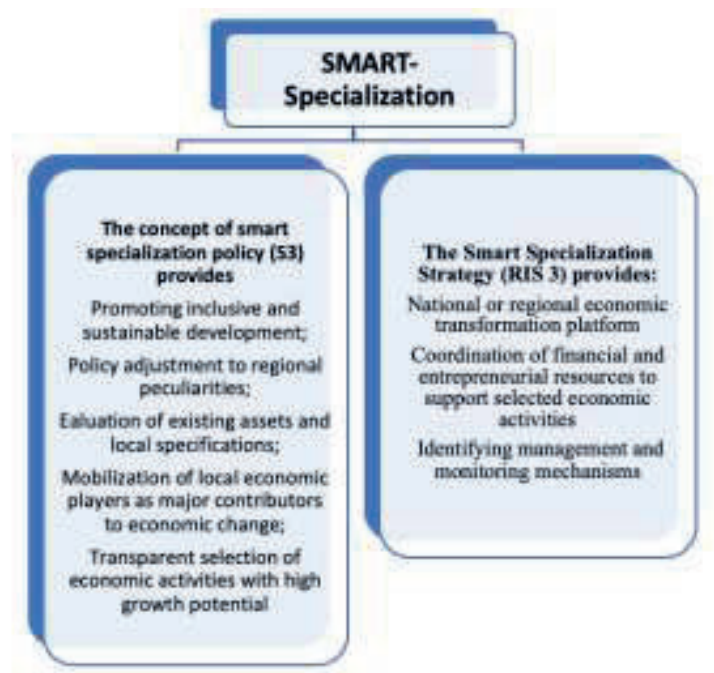

Figure 1a: SMART-Specialization Aspects ${ }^{3}$

Based on the literature analysis, as well as the practical experience of smart specialized networks, we are of the opinion that smart-specialization shall be considered as a two-level process. (Figure 3) The local smart specialization is most often embodied in the form of smart cities, and from the theoretical viewpoint, S3 is the basis for smart city model that even may coincide with it. The regional specialization (RIS3) is fostered and determined by local smart points as drivers of change. Being a region-centered economic model, RIS3 reflects the contribution of public policy to stimulating investment in R\&D and innovation, developing scientific, technological and economic specialization enhancing competitiveness and productivity [18]. There are examples of how regional smartification has been intensified through local smart specialization, which have led to numerous social, political and economic benefits. For instance, the InFocus network consisting of smart cities such as Bilbao (Spain), Bielsko-Biala (Poland), Bordeaux Métropole (France), Bucharest-3rd district (Romania), Frankfurt (German), Grenoble-Alpes Métropole (France), Ostrava (Czech Republic), Plasencia (Spain), Porto (Portugal) and the Metropolitan City of Torino (Italy). [23]

In rare cases, RIS3 may occur spontaneously [3], but most often it is a result of the government's deliberate efforts to support $\mathrm{R} \& \mathrm{D}$, transform production processes and create new lines of business as well as local city development [16 ]. The RIS3 main goals are: [9].

- $\quad$ stimulating the development of new activities with innovative potential;

- $\quad$ expanding the capacity to produce and diversify regional economies;

- $\quad$ the formation of key networks and clusters within a diversified system.

The key features of RIS3:

- business provides an information framework to identify opportunities and prioritize them, while a state creates favorable conditions for development of partnerships [14; 16];

- $\quad$ investment decisions are made irrespective of the source of their origin; preference is given to areas where existing productive assets are effectively complemented by innovative solutions [10].

- $\quad$ any sector or region can become a platform for promising transformation projects, as a result of modernization blurs the boundaries between traditional and new activities [11];

\footnotetext{
${ }^{3}$ Created by Author based on analysis of [23], [16], [14], [13]
} 
- $\quad$ RIS3 is progressive by definition, as it foresees a constant search for new directions and opportunities $[8 ; 10]$;

- $\quad$ smart specialization implies many options for diversification $[2 ; 8 ; 9]$;

- continuous monitoring of implementation and evaluation of RIS3 results against pre-defined criteria as a basis for policy improvement are of a great importance [14]. The process of its development should be extremely flexible, ensuring timely redistribution of state resources in favor of the most viable projects [15].

The practical cases have proved the maximization of economic, social and administrative benefits from smart specialization of both levels. For example, a Spanish Network of Smart Cities (RECI) consisting of 65 cities by the beginning of 2016 has significantly improved public performance of the councilors involved. [13] It allowed more coordinated actions in line with the national innovative policies, better allocation of resources, higher transparency, etc. The regional innovation system is driven by local development and joint policies. In Amsterdam Smart City, smart specialization is treated as a source of modernizing the governmental policies and influencing regional economic development. [1]

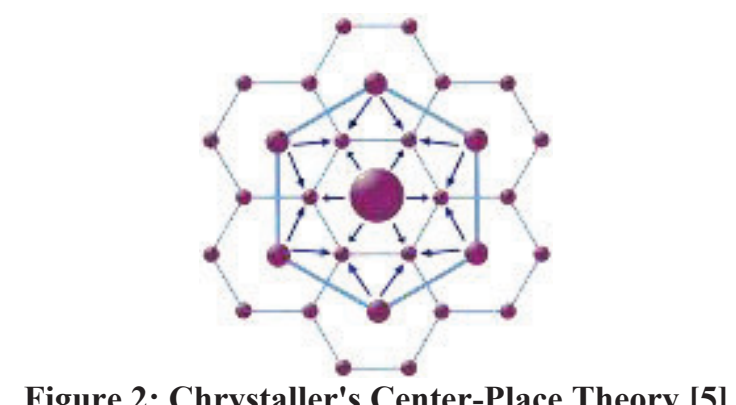

In terms of the regional specialization, similarly to the Chrystaller's Center-Place Theory, smart cities function as attracting points of human, financial and other resources advancing the development of the whole region. The less advantaged parts of the region are becoming more developed through adjusting to level of the leading cities. Because of smart cities, the region acquires additional resources that can be allocated on the modernization of rural areas. Smart Cities are also likely to attract more tourists. Turning a region into a touristic spot also positively affects economic and social situation.

Specialization accelerates networking among cities that may even relate to different regions. Such innovative smart interregional chains may lead to rethinking the governance models prioritizing shared governance and service ecosystems. The administrative boarders are gradually blurred because of the occurrence of the interregional point-to-point smart networks. The European Commission encourages the Interregional Innovative Investment emphasizing on the role of smart specialisation. [14]. In the long-term perspective, there is an attempt to build the pan-European clusters in priority sectors including big data, circular economy, advanced manufacturing, cybersecurity, etc. So, smart areas are likely to facilitate new needs-oriented innovative stage of European integration, where the major role will be played by smart cities and smart regions.

\section{Conclusions and Recommendations for Local and Regional Authorities}

Promoting smart cities and smart specialization as interdependent processes is a very promising tool that could be used by the local and regional authorities to foster economic development and inclusion. The smartification of particular cities is likely to lead to further smartification of a region and vice- 
versa. So, even several territorial points of local smart specialization and consisting innovation contribute to higher development of the adjacent areas and regions. The compatibility of cities and regions comes from systemic specialization on their advantages. The global urbanization processes have resulted in reshaped urban economic systems, in which cities are treated as magnets attracting resources, such as people, investments, and innovations. We do recommend to consider smart cities as triggers of forming larger regional and even interregional specialized networks providing the increased efficiency. Though investing in transforming a city or a region into smart specialized system may be costly, such measure is a promising investment providing increase in GDP, economic development and higher social inclusion.

\begin{tabular}{|l|}
\hline \multicolumn{1}{|c|}{ Stages } \\
\hline $\begin{array}{l}\text { Step 1. Analysis of regional context and innovation } \\
\text { potential }\end{array}$ \\
\hline $\begin{array}{l}\text { Stage 2. Management: stimulating inclusion in the } \\
\text { innovation process }\end{array}$ \\
\hline Stage 3. Development regional joint development \\
\hline Step 4. Setting priorities \\
\hline $\begin{array}{l}\text { Step 5. Defining a coherent integration policy, } \\
\text { roadmaps and action plan }\end{array}$ \\
\hline Step 6. Monitoring and evaluation \\
\hline
\end{tabular}

Figure 3: Regional Specialization Stages ${ }^{4}$

Though the stages of regional specialization shall be adjusted to particular needs and circumstances of an area, Figure 3 provides the overall algorithm that could be used by local and regional authorities to foster positive results. The monitoring shall take place throughout the whole period of smart city or smart region implementation.

The following scopes to be taken into account by authorities are likely to facilitate their efficiency while implementing smart solutions.

\section{Local Level}

- $\quad$ Ensuring open data and their accessibility

- $\quad$ Conducting researches on the citizen's needs, ensuring Inclusivity

- Studying factors of local environment to determine competitive advantages and directions of specialization

- $\quad$ Ensuring quality education to allow citizens to adjust to new market needs

- $\quad$ Promoting Internet of Things

- $\quad$ Promoting e-governance

- Systemic realization of smart city concept based on consultations and cooperation with the adjacent cities, rural areas, region, adjacent regions and national authorities, business circles and academic institutions

- Involving citizens, local businesses, educational institutions into decision-making processes

- Advancing innovations while tackling digital divide

- $\quad$ Preventing corruption related to smart specialization

- Initiating tests of innovative programs

- Monitoring the smart city performance to make it flexible to new arriving needs

\footnotetext{
${ }^{4}$ Created by author
} 
- $\quad$ Establishing special smartification teams consisting from city council members, business professionals, researchers to guide the smart transformation.

- Integrating risk management strategy into the operational strategy, preparing and preliminary testing risk plans on different scenarios in case of unexpected crisis, environmental collapses, etc. (black swans as described by Nassim Taleb)

\section{Regional Level}

- Coordinating local smart iniatives

- $\quad$ Determining the regional smart priorities, ensuring Inclusivity

- Studying the needs of residents of the whole region and comparing them to the needs of residents of particular consisting urban and rural areas

- $\quad$ Advancing IoT, digitalization, smartification to ensure steady development of all city and rural areas

- $\quad$ Promoting smart education

- $\quad$ Supporting business iniatives complying with the specialization strategies

- Encouraging interregional, national and international consultations on smart specialization to coordinate the efforts

- $\quad$ Establishing special smartification teams consisting from city council members, business professionals, researchers to guide the smart transformation

- Integrating risk management strategy into the operational strategy, preparing and preliminary testing risk plans on different scenarios in case of unexpected crisis, environmental collapses, etc. (black swans as described by Nassim Taleb).

Summarizing the strategies and priorities discussed, we shall also note the following important principles:

- Cooperation and coordination of efforts of the municipality with the private sector, research institutes, civil society

- $\quad$ Focus on the interests of residents (inclusivity, involvement, protection)

- $\quad$ Ensuring open data and their accessibility

- $\quad$ Resource management efficiency

- $\quad$ Adhering to common standards when designing and implementing intelligent solutions

- $\quad$ Ensuring the exchange of experience and knowledge at national and international levels

- Developing digital leadership and skills

- $\quad$ Building infrastructure and increasing the access to ICT for a wide range of people

- Creating a regional smart city platform for communication among local smart iniatives, project publication, event organizing, etc.

\section{References}

[1] AMSTERDAM SMART CITY. URL: https://amsterdamsmartcity.com.

[2] ASHEIM B., GRILLITSCH M. and TRIPPL M., (2017) Smart Specialization as an InnovationDriven Strategy for Economic Diversification: Examples From Scandinavian Regions. Advances in the Theory and Practice of Smart Specialization (eds. S. Radošević, A. Curaj, R. Gheorghiu, I. Wade), Amsterdam: Academic Press, pp. 73-97. Available at: 
https://doi.org/10.1016/B978-0-12-804137-6.00004-8, accessed 01.02.2012.

[3] BOSCHMA, R., (2013) Constructing Regional Advantage and Smart Specialization: Comparison of Two European Policy Concepts (Evolutionary Economic Geography Series Paper no 13.22), Utrecht: University of Utrecht.

[4] BOSCHMA, R., (2016) Smart Specialisation and Regional Innovation Policy. Welsh Economic Review, vol. 24, p. 17. Available at: https://doi. org/10.18573/j.2016.10050, accessed 05.02.2020.

[5] CENTRAL-PLACE THEORY | economics and geography. Encyclopedia Britannica. (2020). Retrieved 03 February 2020, from https://www.britannica.com/topic/central-place-theory

[6] CITIES AS ENGINES OF ECONOMIC GROWTH. (2020). Retrieved 10 February 2020, from https://pubs.iied.org/pdfs/10801IIED.pdf

[7] CRESPO J., BALlAND P.-A., BOSCHMA R. and RIGBY D., (2017) Regional Diversification Opportunities and Smart Specialization Strategies, Brussels: European Commission.

[8] FORAY D., Guide to Research and Innovation Strategies for Smart Specialisation (RIS 3) / Foray D. et al. [Електронний pecypc]. Joint Research Center, 2012. URL:http://s3platform.jrc.ec.europa.eu/documents/20182/84453/RIS3+Guide.pdf/fceb8c5873a9-4863- 8107-752aef77e7b4

[9] FORAY D. and GOENAGA X., (2013) The Goals of Smart Specialisation (JRC Scientific and Policy Reports - S3 Brief Series no 1), Brussels: European Commission.

[10] FORAY D., MORGAN K. and RADOSEVIC S., (2018) The Role of Smart Specialisation in the EU Research and Innovation Policy Landscape, Brussels: European Commission. Available at: http://ec.europa.eu/regional_policy/sources/docgener/brochure/smart/role_smart specialisation_ri.pdf, accessed 13.01.2020.

[11] GHEORGHIU R., ANDREESCU L., ZULEAN M. and CURAJ A., (2017) Entrepreneurial Discovery as a Foresight for Smart Specialization: Trade-Offs of Inclusive and Evidence-Based Consensus. Advances in the Theory and Practice of Smart Specialization (eds. S. Radošević, A. Curaj, R. Gheorghiu, I. Wade), Amsterdam: Academic Press, pp. 319-344. Available at: https://doi.org/10.1016/B978-0-12-804137-6.00014-0, accessed 09.02.2020.

[12] HOW SMART CITY INVESTMENT CAN UNLOCK ECONOMIC GROWTH. Smart Cities World. (2020). Retrieved 9 February 2020, from https:/www.smartcitiesworld.net/news/ news/how-smart-city-investment-can-unlock-economic-growth-3566.

[13] IMPACT ANALYSIS OF SMART CITY NETWORKS IN CITIES' LOCAL GOVERNMENT. Coit.es. (2020). Retrieved 10 February 2020, from https://www.coit.es/sites/ default/files/informes/pdf/impact_analysis_of_smart_city_networks_in_cities_local_governm ent.pdf. 
[14] ISSUES NOTE SMART CITIES AND INCLUSIVE GROWTH. Oecd.org. (2020). Retrieved 10 February 2020, from http://www.oecd.org/cfe/regional-policy/OECD-Roundtable-onSmart-Cities-and-Inclusive-Growth_Issues-Note.pdf

[15] KOTNIK P. and PETRIN T., (2017) Implementing a smart specialisation strategy: An evidence-based approach. International Review of Administrative Sciences, vol. 83, no 1, pp. 85-105. Available at: https://doi.org/10.1177/0020852315574994, accessed 15.01.2019.

[16] LANDABASO M., MCCANN P. and ORTEGA-ARGILÉS R., (2014) Smart specialisation in European regions: Issues of strategy, institutions and implementation. European Journal of Innovation Management, vol. 17, no 4, pp. 409-427. Available at: https://doi.org/10.1108/ EJIM-05-2014-0052, accessed 02.03.2019.

[17] MAYER-SCHONBERGER, V. and CUKIER, K., (2013). Big Data: A revolution that will transform how we live, work and think. John Murray (Publishers), London.

[18] MCCANN P. and ORTEGA-ARGILÉS R., (2013) Smart Specialization, Regional Growth and Applications to European Union Cohesion Policy. Regional Studies, vol. 49, no 8, pp. 12911302. Available at: https://doi.org/10.1080/00343404.2013.799769, accessed 22.12.2018.

[19] MCCANN P. and ORTEGA-ARGILÉS R., (2016a) The early experience of smart specialization implementation in EU cohesion policy. European Planning Studies, vol. 24, no 8, pp. 1407-1427. Available at: https://doi.org/10.1080/09654313.2016.1166177, accessed 22.12.2018.

[20] NEAL, Z. P., (2013). The connected city: How networks are shaping the modern metropolis. Routledge, New York \& London.

[21] NEW COHESION POLICY. Ec.europa.eu. (2020). Retrieved 24 February 2020, from https://ec.europa.eu/regional_policy/en/2021_2027/.

[22] NEWMAN, M., (2010). Networks: An Introduction. Oxford University Press, Oxford.

[23] RIVAS, M., (2018) Smart Specialisation at City Level. URBACT-InFocus final report.

[24] SMART CITIES ARE GETTING SMARTER IN SURPRISING WAYS. Abiresearch.com. (2020). Retrieved 24 February 2020, from https://www.abiresearch.com/press/smart-cities-aregetting-smarter-surprising-ways/.

[25] SMART CITIES COUNCIL (2015). Smart cities readiness guide: The planning manual for building tomorrows cities today.

[26] SMART CITIES: DIGITAL SOLUTIONS FOR A MORE LIVABLE FUTURE. McKinsey \& Company. (2020). Retrieved 4 February 2020, from https://www.mckinsey.com/industries/ capital-projects-and-infrastructure/our-insights/smart-cities-digital-solutions-for-a-morelivable-future.

[27] TAPLIN, T. B., (2019). Economic Potential of Smart Cities. New York 
[28] TOWNSEND, A. M., (2013). Smart Cities: Big data, civic hackers, and the quest for a new utopia. W.W. Norton \& Company Inc. New York.

[29] WADHWA, M., Understanding the Impact of Smart Cities and the Need for Smart Regulations (July 15, 2015). Available at SRN: https://ssrn.com/abstract=2908 299 or http://dx.doi.org/10.2139/ssrn.2908299

[30] WESAM, M., (2020). The Impact of Smart City Initiatives on Cities' Local Economic Development. Scholars.fhsu.edu. Retrieved 10 February 2020, from https://scholars.fhsu.edu/ cgi/viewcontent.cgi?article $=1500 \&$ context $=$ theses .

[31] WELLINGTON, P., (2019). Smart City Concept Evolution. Journal of Economic Development. New York. 